\title{
SISTEM INFORMASI PENERIMAAN PEGAWAI PADA PT. SIANYU PERKASA
}

\author{
Rama Saputra ${ }^{1}$, Tuti Handayani ${ }^{2}$, Rosdiana ${ }^{3}$ \\ Program Studi Informatika, Universitas Indraprasta PGRI ${ }^{1}$ \\ Email: saputra.rama99@gmail.com ${ }^{1}$; tuti.hani80@gmail.com ${ }^{2}$; rosdianasidik.rs@gmail.com ${ }^{3}$
}

Riwayat Diterima 5 Sept 2020 Revisi 7 Oct, 2020 Disetujui 20 Nov 2020 Terbit 30 Nov 2020

Kata Kunci Penerimaan, Pegawai, waterfall, dan Java.

\begin{abstract}
Article history Received Sep 5, 2020

Revised Okt 7 , 2020 Accepted Nov 20, 2020

Available online Nov 30, 2020

Keywords Recruitment, Employee, waterfall, and Java.

The main purpose of the recruitment process is to get the right people for the right position adapted to the conditions and needs of the organization or company. The problems were faced by companies begin with how to provide information that can facilitate the recruitment of workers to handle the recruitment process. The author makes several limitations. First, this support system is used by HRD as part of the recruitment of workers. And second, this system is only used as a recruitment process at PT. Sianyu Perkasa. The system development model use a waterfall process model which is systematic and sequential. The design of this system uses the Java programming language and XAMPP as a web server that is supported by MySQL as the data processor. Some things obtained from this research are the information system can provide information about recruitment that is processed by the HRD. This information system simplifies the process of selecting prospective employee data and making reports. The suggestion that the writer can convey in this research is the need for training, to use this information system by HRD and this information system can still be developed following the changing needs of the company later.
\end{abstract}

Key Words : Recruitment, Employee, waterfall, and Java.

\section{Abstrak}

Tujuan utama dari proses penerimaan pegawai adalah untuk mendapatkan orang yang tepat pada penempatan yang tepat pula sehingga sesuai dengan kondisi dan kebutuhan organisasi atau perusahaan. Permasalahan yang dihadapi perusahaan dimulai dengan bagaimana menyajikan informasi yang dapat mempermudah bagian perekrutan tenaga kerja dalam menangani proses penerimaan pegawai. Penulis melakukan beberapa batasan antara lain sistem pendukung ini digunakan oleh HRD selaku bagian perekrutan tenaga kerja. Serta Sistem ini hanya digunakan sebagai proses penerimaan tenaga kerja di PT. Sianyu Perkasa. Model pengembangan sistem yang digunakan adalah model proses waterfall yang bersifat sistematis dan berurutan. Perancangan sistem ini menggunakan bahasa pemrograman Java dan XAMPP sebagai web server yang didukung dengan MySQL sebagai pengolah datanya. Beberapa hal yang didapat dari penelitian ini adalah sistem informasi ini dapat memudahkan penyajian informasi mengenai penerimaan pegawai yang diolah oleh bagian HRD. Serta sistem informasi ini mempermudah proses penyeleksian data calon pegawai dan pembuatan laporan. Saran yang dapat penulis sampaikan dalam penelitian ini adalah perlu adanya pelatihan penggunaan sistem informasi ini kepada bagian HRD dan sistem informasi dapat dikembangkan sesuai dengan perubahan kebutuhan perusahaan nantinya.

Kata Kunci : Penerimaan, Pegawai, waterfall, dan Java. 


\section{PENDAHULUAN}

Salah satu kegiatan yang paling penting dalam suatu perusahaan atau organisasi adalah masalah sumber daya manusia. Karena, fokus utama manajemen sumber daya manusia adalah memberikan kontribusi sukses atau tidaknya suatu perusahaan. Manajemen sumber daya manusia sendiri tidak hanya mengatur pegawai yang ada dalam perusahaan, tetapi dimulai dari pemilihan calon pegawai, penilaian suatu kinerja pegawai, pemilihan dan penempatan pegawai serta pengisian jabatan yang sesuai dengan kepatutan dan kelayakan.

PT. Sianyu Perkasa merupakan salah satu mitra dari perusahaan PT. Telekomunikasi Seluler yang bergerak dalam bidang distribusi produkproduk dari PT. Telekomunikasi Seluler yang sangat mengutamakan kualitas dalam menjalankan tugasnya. Oleh karena itu, dibutuhkan tenaga-tenaga ahli yang terampil dan professional guna menunjang hal tersebut. Semakin banyaknya tenaga kerja yang memiliki kemampuan yang berbeda, maka dalam merekrut pegawai baru diperlukan penyeleksian dari calon pegawai yang melamar pada PT. Sianyu Perkasa, selama ini proses penyeleksian tersebut masih dilakukan secara manual sehingga menyulitkan bagian penerimaan pegawai dan juga rawan akan terjadinya suatu kesalahan dalam mengambil keputusan, selain itu juga akan memerlukan waktu yang cukup menyita. Dengan mempertimbangkan hal tersebut, maka diperlukan suatu sistem yang dapat berfungsi sebagai pendukung keputusan dari setiap calon pegawai yang mendaftar dengan kriteria yang beraneka ragam yang mereka miliki. Dengan melakukan sistem sebagai pendukung keputusan tentu hal tersebut akan sangat menghemat waktu dan mengurangi risiko terjadi kesalahan dalam posisi yang dibutuhkan oleh perusahaan.

Tinjauan pusataka yang relevan dengan penelitian ini adalah :

a. Penelitian yang dilakukan oleh Ridwan Jaeni Adina pada tahun 2017 dari Universitas Indraprasta PGRI, yang berjudul "Sistem Penunjang Keputusan Penilaian Karyawan Terbaik Menggunakan Metode AHP di PT. Trimitra Utama”. Penelitian ini membahas tentang rancangan program aplikasi sistem penunjang keputusan untuk penilaian karyawan.

b. Penelitian yang dilakukan oleh Vini Lorita Idris pada tahun 2017 dari Universitas Indraprasta PGRI, yang berjudul "Sistem Pendukung Penerimaan Karyawan pada PT. ISS Indonesia". Penelitian ini membahas tentang membuat rancangan program aplikasi sistem penunjang keputusan untuk penerimaan karyawan.

c. Penelitian yang dilakukan oleh Shita Prastika pada tahun 2018 dari Universitas Indraprasta PGRI, yang berjudul "Sistem Pendaftaran dan Seleksi Penerimaan Kurir pada Westbike Messenger Service dengan Metode AHP". Penelitian ini membahas tentang Membuat rancangan program aplikasi sistem penunjang keputusan untuk penyeleksian kurir.

\section{KAJIAN LITERATUR}

Dalam referensi [1] menyebutkan bahwa sistem dan sistem informasi adalah suatu hal yang saling berhubungan satu dengan yang lainnya yang akhirnya menghasilkan sebuah informasi atau data yang berguna bagi orang yang dituju sesuai dengan peruntukannya.

Dalam referensi [2] menyebutkan rekrutmen adalah proses yang dilakukan perusahaan dalam menyebarkan informasi dan membuka akses seluas-luasnya guna menjaring pelamar. Jalur jalur yang biasa digunakan perusahaan saat ini adalah melalui iklan lowongan kerja di media cetak, radio televisi. website. kerja sama dengan agen penampung tenaga kerja, atau rekrutmen langsung ke sekolah atau kampus.

Tujuan utama dari proses penerimaan pegawai adalah untuk mendapatkan orang yang tepat pada penempatan yang tepat pula sehingga sesuai dengan kondisi dan kebutuhan organisasi atau perusahaan. Perusahaan yang baik akan senantiasa mencari individu yang mempunyai etos kerja yang baik. Ketika hal tersebut telah dimiliki oleh sebuah organisasi atau perusahaan maka dia akan mampu bertahan di tengah persaingan yang penuh dengan kompetisi dan perubahan yang begitu cepat.

Dalam referensi [3] menyebutkan sebuah 
sistem informasi berbasis komputer sudah diteliti dan dirancang yang memiliki manfaat mempermudah perusahaan dalam melakukan pengarsipan surat masuk dan surat keluar pada CV. Sumber Karya Teknik.

Dalam referensi [4] menyebutkan bahwa merancang sistem aplikasi dibutuhkan tahapan pada langkah-langkah pembuatan sistem, tahapan perancangan memiliki tujuan untuk mendesain sistem baru yang dapat menyelesaikan masalah-masalah yang dihadapi oleh perusahaan untuk memilih alternatifalternatif terbaik pada sistem.

Dalam merekrut pegawai baru diperlukan penyeleksian dari calon pegawai yang melamar pada PT. Sianyu Perkasa, selama ini proses penyeleksian tersebut masih dilakukan secara manual sehingga menyulitkan bagian penerimaan pegawai dan juga rawan akan terjadinya suatu kesalahan dalam mengambil keputusan, selain itu juga akan memerlukan waktu yang cukup menyita.

Tujuan dari penelitian yang hendak dicapai sebagai berikut:

1. Membangun sistem Penerimaan Pegawai pada PT. Sianyu Perkasa yang dapat mengolah data calon pegawai sehingga mempermudah bagian HRD dalam mencari data calon pegawai.

2. Mempermudah bagian HRD PT. Sianyu Perkasa dalam menyeleksi calon pegawai.

3. Membangun sistem yang mengolah data calon pegawai dalam satu database yang dapat mempermudah penyeleksian calon pegawai oleh bagian HRD.

4. Membangun sistem pendukung menggunakan bahasa pemrograman Java dan database MySQL yang dapat mengurangi kesalahan penerimaan pegawai pada PT. Sianyu Perkasa.

5. Memudahkan kinerja bagian HRD dalam melakukan penyeleksian calon pegawai secara obyektif, keputusan yang dihasilkan lebih baik dan akurat, jserta dapat menghasilkan laporan dengan tepat waktu.

Adapun manfaat dari penelitan ini bagi penulis yaitu mendapatkan pengetahuan dan wawasan di bidang penerimaan pegawai beserta pembuatan sistem informasinya berbasis Java. Sedangkan manfat bagi perusahaan adalah dapat membantu bagian HRD PT Sianyu perkasa dalam menyeleksi pegawai baru yang sesuai dengan kriteria yang diinginkan oleh perusahaan, pendataan yang lebih efisen, dan pembuatan laporan kepada pimpinan.

\section{METODE PENELITIAN}

Dalam referensi [5] menyebutkan bahwa penelitian kualitatif adalah jenis penelitian yang temuan-temuannya tidak diperoleh melalui prosedur statistik atau bentuk hitungan lainnya dan bertujuan mengungkapkan gejala secara holistik-kontekstual melalui pengumpulan data dari latar alami dengan memanfaatkan diri peneliti sebagai instrumen kunci.

Penelitian ini menggunakan pendekatan kualitatif karena data yang diperoleh bukan melalui prosedur statistik atau bentuk hitungan lainnya. Dalam penyusunan skripsi ini, penulis berusaha mendapatkan data yang cukup dengan cara pengumpulan bahan-bahan keterangan dan data yang dibutuhkan untuk membuat sistem informasi penerimaan pegawai pada PT. Sianyu Perkasa, sehingga tidak menyimpang dari pokok permasalahan

Dalam referensi [6] menyebutkan bahwa metode penelitian dan pengembangan atau dalam bahasa Inggrisnya Research and Development adalah metode penelitian yang digunakan untuk menghasilkan produk tertentu, dan menguji keefektifan produk tersebut.

Selain itu dalam referensi [7] menunjukkan bahwa waterfall merupakan salah satu metode dalam SDLC yang mempunyai ciri khas pengerjaan yaitu setiap fase dalam waterfall harus diselesaikan terlebih dahulu sebelum melanjutkan ke fase selanjutnya.

Penelitian ini menggunakan metode penelitian dan pengembangan (Research and Development) yang digunakan untuk menghasilkan produk yang berupa sistem informasi penerimaan pegawai pada PT. Sinayu Perkasa dan untuk menguji keefektifan sistem informasi tersebut. Model pengembangan sistem yang digunakan adalah model proses waterfall. Model proses waterfall adalah model klasik yang bersifat sistematis, berurutan dalam membangun suatu perangkat lunak

Langkah-langkah yang dilakukan dalam penelitian dan perancangan sistem informasi penerimaan pegawai adalah: 
1. Analisa Kebutuhan Sistem

Untuk mendapatkan data-data yang akan digunakan sebagai masukkan dari suatu sistem dan untuk memperoleh data yang berhubungan dengan skripsi ini. Penulis meninjau langsung proses penerimaan pegawai yang ada pada PT. Sianyu Perkasa. Langkah selanjutnya adalah kita perlu memahami user. Kita harus mengetahui apa yang diinginkan dan dibutuhkan oleh user.

2. Kajian Dokumen

Penulis melakukan kajian dokumen berdasarkan referensi dan berbagai diskusi pembahasan dengan dosen pembimbing. Kajian dokumen bertujuan untuk mempelajari dan memahami dasar teori yang berhubungan dengan analisa kebutuhan yang telah dilakukan. Selain itu penulis juga melakukan kajian dari beberapa buku yang berkaitan guna menyelesaikan skripsi ini.

3. Perancangan Sistem

Untuk merancang sistem yang akan dibuat agar dapat diimplementasikan dengan kebutuhan pengguna. Langkah yang dilakukan dalam perancangan sistem informasi ini adalah:

a. Merancang database

Database digunakan untuk menyimpan data-data yang telah dimasukkan. Dalam merancang database, terlebih dahulu kita membuat tabel-tabel data kemudian menentukan primary key dari setiap tabel, serta menentukan relationship dari setiap tabel.

b. Merancang antarmuka

Dalam merancang antarmuka atau tampilan ada beberapa hal yang harus diperhatikan agar tampilan dalam sistem informasi yang kita buat lebih menarik bagi user. Salah satunya dengan membuat sistem informasi yang sesederhana mungkin sehingga memudahkan user dalam menggunakan dan memahaminya. Dalam melakukan perancangan penulis menggunakan media pembantu dalam penggambaran tampilan sistem informasi, serta fungsi dan keterkaitan antar satu form dan form lainnya, beserta hasil dari laporannya.

c. Evaluasi antarmuka

Untuk dapat menilai sebuah program sesuai dengan keinginan user, penulis menanyakan langsung kepada user perihal desain, kegunaan dari setiap form, dan bentuk laporan nantinya. Jika user masih menginginkan perubahan baik dalam bentuk desain, form, ataupun laporannya, maka perlu diubah kembali rancangan yang telah dibuat, selama perubahan tersebut masih dalam ruang lingkup sistem informasi penerimaan pegawai.

4. Pengembangan Sistem

Setelah melakukan perancangan antarmuka yang diinginkan oleh user, penulis mengembangkan antarmuka ke dalam bentuk sebuah program. Dengan tanpa mengubah rancangan antarmuka awal beserta dengan fungsi dan keterkaitan antar form, ditambah laporan hasil dari sistem informasi tersebut. Sehingga menghasilkan sistem informasi penerimaan pegawai pada PT. Sianyu Perkasa.

5. Pengujian Sistem

Suatu proses untuk memastikan apakah semua fungsi sistem bekerja dengan baik, dan mencari ada tidaknya kesalahan pada sistem. Pengujian sangat penting untuk dilakukan untuk menjamin kualitas sebuah sistem informasi, dan juga menjadi peninjauan terakhir terhadap spesifikasi, desain, dan pengodean sistem informasi tersebut.

6. Implementasi

Langkah terakhir adalah penerapan sistem informasi yang telah dibuat ke dalam perusahaan, khususnya pada bagian HRD. Proses ini harus sesuai dengan perencanaan yang telah dibuat agar hasil yang dicapai sesuai dengan yang diharapkan.

\section{HASIL DAN PEMBAHASAN}

\section{A. Hasil}

Berikut ini adalah Diagram Alir Data sistem informasi penerimaan pegawai pada PT. Sianyu Perkasa : 


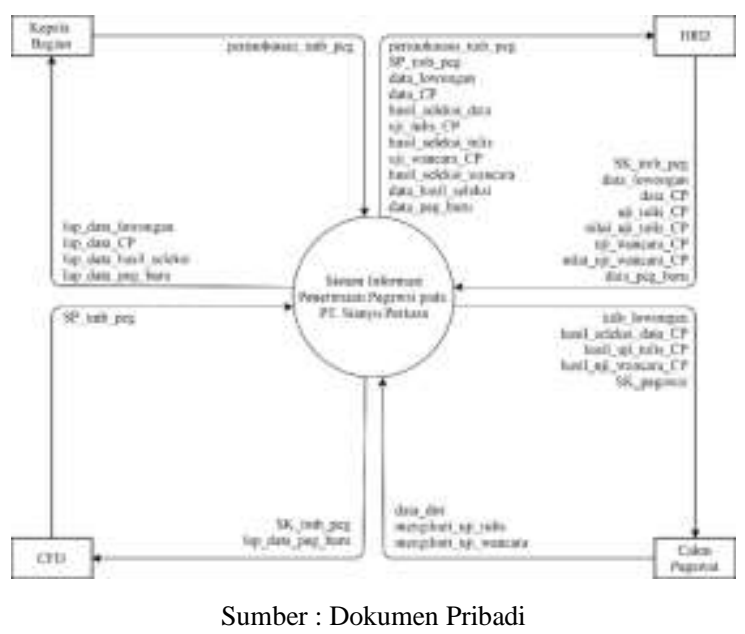

Gambar 1. Diagram Alir Data

Di bawah ini adalah Entity Relationship Diagram yang disusun oleh penulis untuk sistem informasi penerimaan pegawai pada PT. Sianyu Perkasa :

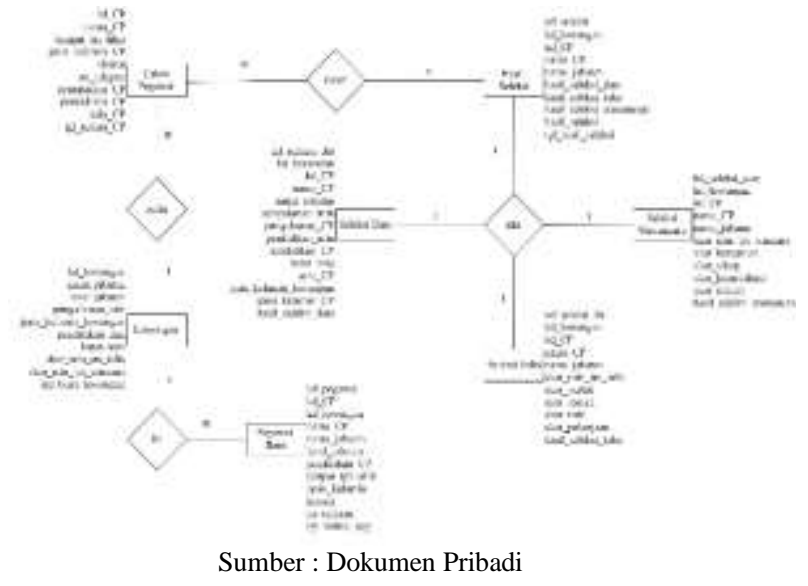

Gambar 2. Diagram ERD Sistem

Tampilan Aplikasi Sistem

1. Login

Tampilan awal atau login dari sistem informasi. Untuk dapat menggunakan sistem, user diharuskan mengisi user name dan password.

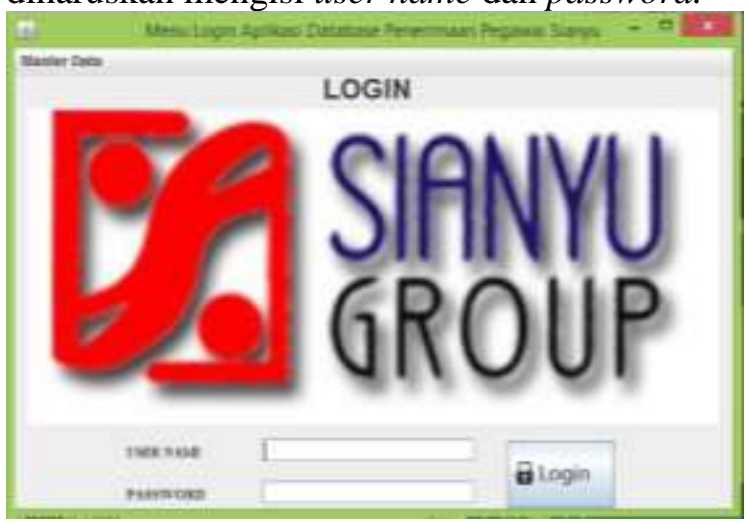

Sumber : Dokumen Pribadi

\section{Gambar 3. Tampilan Layar Login}

\section{Menu Utama}

Tampilan menu utama sistem terdiri dari beberapa pilihan menu-menu lainnya yang dapat dimasuki oleh pengguna. Ketika kita memilih lowongan maka akan diarahkan kepada data lowongan, bila kita memilih calon pegawai maka akan diarahkan kepada data calon pegawai, begitu pula seterusnya.

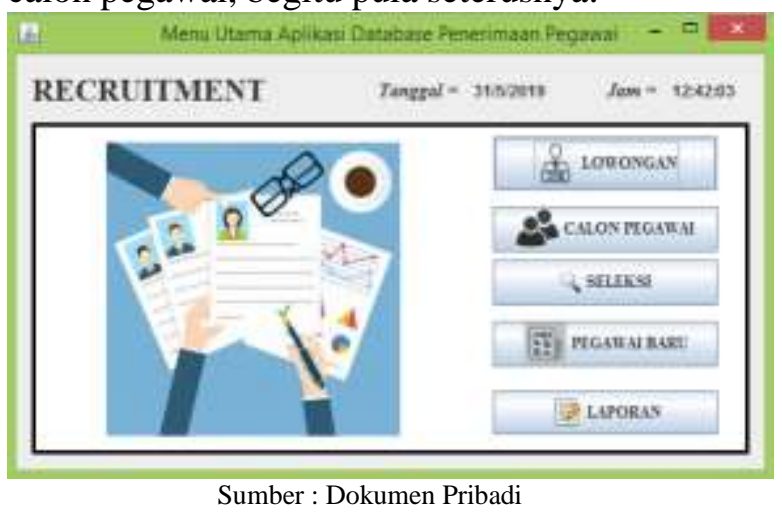

\section{Gambar 4. Tampilan Layar Menu Utama}

\section{Lowongan}

Tampilan data lowongan, terdiri dari data dan kualifikasi lowongan yang dibutuhkan perusahaan. Beberapa fungsi yang ada dalam sistem antara lain menyimpan, mengubah, dan menghapus data lowongan.

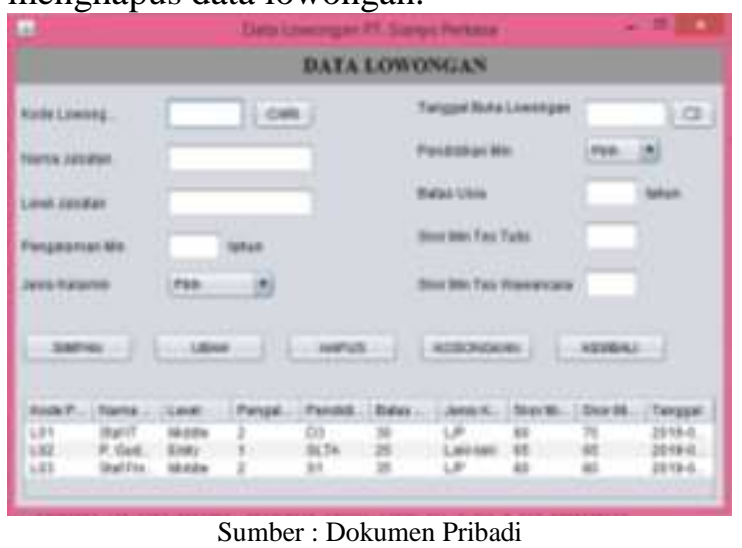

\section{Gambar 5. Tampilan Layar Data Lowongan}

\section{Calon Pegawai}

Tampilan data calon pegawai, terdiri dari data diri dari calon pegawai. Beberapa fungsi yang ada dalam sistem antara lain menyimpan, mengubah, dan menghapus data calon pegawai. 


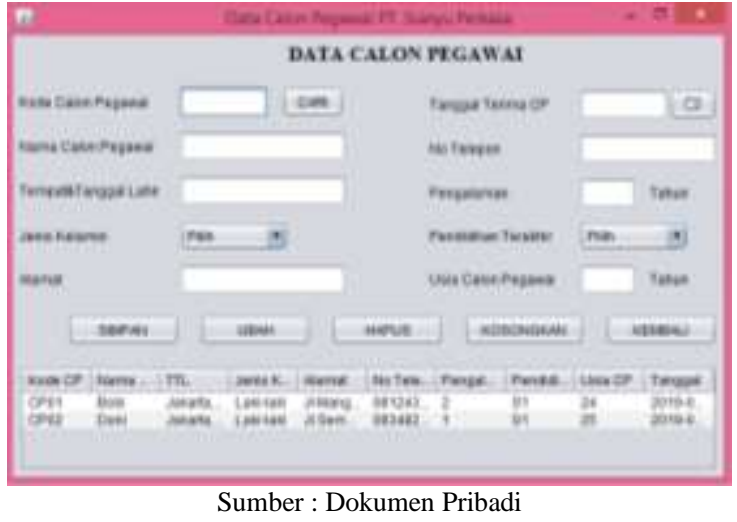

Gambar 6. Tampilan Layar Data Calon Pegawai

\section{Seleksi}

Tampilan seleksi calon pegawai terdiri dari beberapa menu lainnya seperti seleksi data, seleksi uji tulis, seleksi uji wawancara, dan hasil seleksi yang semuanya saling berkaitan satu sama lain. Setiap data yang dimiliki oleh calon pegawai pada menu seleksi akan dibandingkan dengan kriteria yang dibutuhkan dari perusahaan.

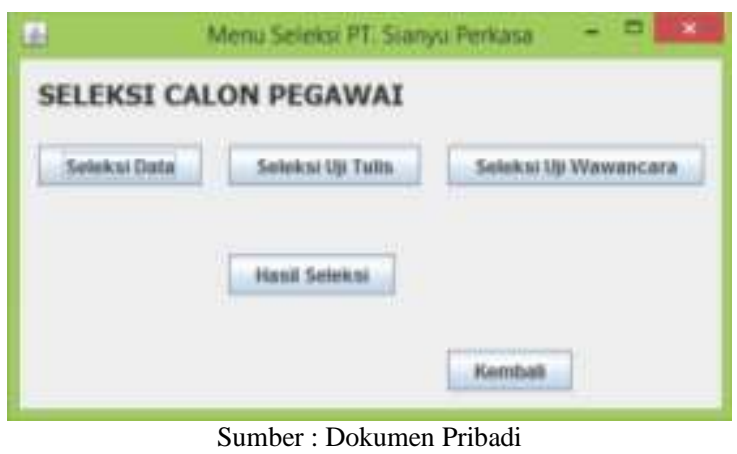

\section{Gambar 7. Tampilan Layar Seleksi Calon Pegawai}

\section{Pegawai Baru}

Tampilan data pegawai baru, terdiri dari data diri dari pegawai baru. Dengan mengetikan kode seleksi maka data diri pegawai akan otomatis muncul. Beberapa fungsi yang ada dalam sistem antara lain menyimpan, mengubah, dan menghapus data pegawai baru. Ada pula fungsi lain seperti kosongkan kolomkolom serta kembali ke menu utama.

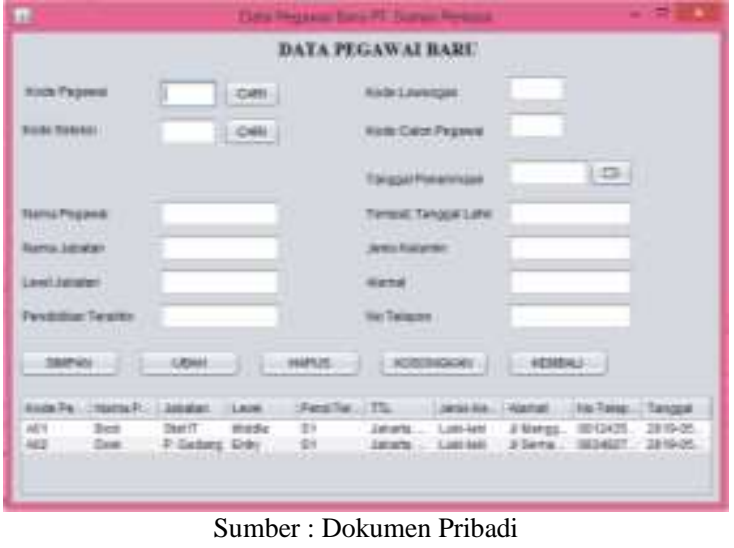

\section{Gambar 8. Tampilan Layar Data Pegawai} Baru

\section{Pembuatan Laporan}

Tampilan pembuatan laporan terdiri dari beberapa pilihan pembuatan laporan lainnya seperti pembuatan laporan data lowongan, data calon pegawai, data hasil seleksi, dan data pegawai baru. Pembuatan laporan dapat disesuaikan dengan tanggal dibuatnya data tersebut.

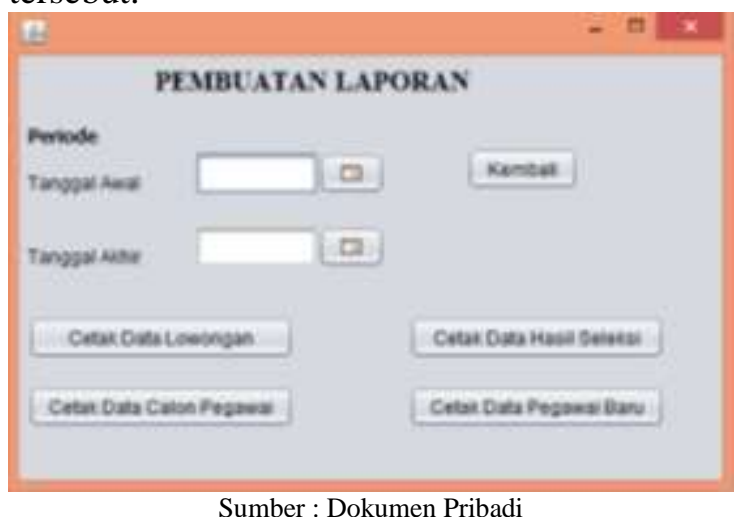

\section{Gambar 9. Tampilan Layar Pembuatan Laporan}

\section{Laporan}

Terdapat empat jenis laporan yang dapat dicetak di dalam sistem antara lain, laporan data lowongan, laporan data calon pegawai, laporan data hasil seleksi, dan laporan data pegawai baru. Keempatnya dapat dicetak sesuai dengan periode waktu yang diinginkan oleh $u$ ser. 


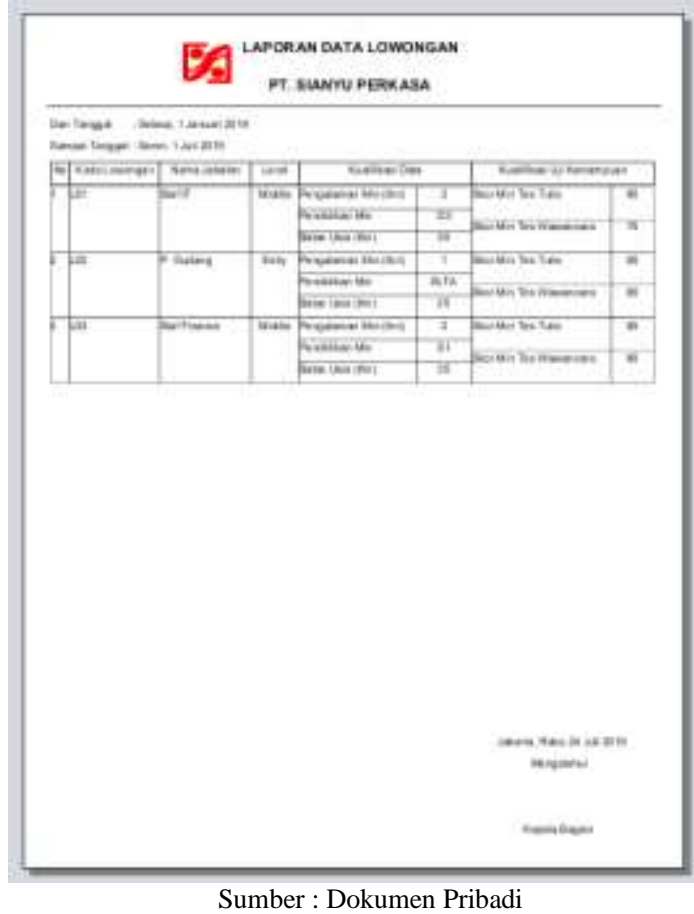

Gambar 10. Tampilan Layar Laporan

\section{B. Pembahasan}

Setelah melihat dan melakukan observasi pada prosedur sistem berjalan penerimaan pegawai pada PT. Sianyu Perkasa, penulis masih menemukan permasalahan di mana keadaan tersebut kurang efektif dalam proses penyimpanan data, penyeleksian pegawai, pencarian data, dan pembuatan laporan.

Adapun akar dari setiap permasalahan yang ada karena proses pendataan yang masih bersifat manual menggunakan Microsoft Excel, di mana proses pendataan masih kurang efisien. Selain itu perusahaan juga belum menggunakan sistem informasi yang baik sehingga membuat lambatnya pekerjaan HRD dalam menjalankan tugasnya.

Alternatif yang ditawarkan dalam menyelesaikan permasalahan yang ada adalah dengan membuat sistem informasi berbasis Java di mana kelebihannya dapat memberikan kemudahan dalam menjalankan pengolahan data seperti data lowongan yang tersedia dan data para calon pegawai. Selain itu pengolahan data dilakukan secara terstruktur, sehingga mempermudah dalam melakukan pencarian data, penyeleksian pegawai maupun membuat laporan.

1. Pembukaan lowongan Pembukaan lowongan dilakukan pada saat salah satu kepala bagian membutuhkan pegawai baru. Yang diajukan kepala bagian oleh HRD dan dilanjutkan kepada CFO untuk mendapatkan persetujuannya. Dilanjutkan dengan bagian HRD yang membuka lowongan pekerjaan dan memasukan ke berbagai situs pencari kerja.

2. Pendataan calon pegawai Para Calon pegawai yang menerima info lowongan melamar pekerjaan dengan memberikan data diri mereka, yang kemudian akan didata satu persatu, dari data calon pegawai sistem akan menentukan pegawai yang memenuhi kriteria lowongan

3. Penilaian uji tulis calon pegawai Setelah lulus seleksi data, para calon pegawai mengikuti seleksi uji tulis. HRD akan menilai uji tulis calon pegawai dan disimpan ke dalam sistem, kemudian sistem akan menyeleksi calon pegawai sesuai kriteria lowongan

4. Penilaian uji wawancara calon pegawai Setelah lulus seleksi data, para calon pegawai mengikuti seleksi uji wawancara. HRD akan menilai langsung wawancara dengan calon 73 pegawai, nilai uji wawancara disimpan ke dalam sistem, kemudian sistem akan menyeleksi calon pegawai sesuai kriteria lowongan.

5. Penerimaan pegawai Data-data seleksi yang tersimpan di dalam sistem akan menghasilkan data hasil seleksi. Dari data hasil seleksi diketahui calon pegawai yang telah lolos semua seleksi, dan didata kembali ke dalam data pegawai baru. Para pegawai baru akan menerima SK pegawai. .

6. Pembuatan laporan Pembuatan laporan dilakukan setiap periode yang ditentukan oleh atasan biasanya antara tiga sampai empat bulan sekali. Data-data yang sudah disimpan di dalam sistem akan dipila dan dibuat laporannya secara otomatis sesuai dengan tanggalnya dan jenis laporannya. Yang nantinya laporan tersebut akan diserahkan kepada kepala bagian maupun CFO. 


\section{KESIMPULAN}

Berdasarkan kegiatan yang telah dilakukan oleh penulis di PT. Sianyu Perkasa, maka dapat disimpulkan sebagai berikut:

1. Untuk dapat memudahkan penyajian informasi maupun laporan penerimaan pegawai dengan menggunakan sistem informasi berbasis Java yang diolah oleh bagian HRD.

2. Sistem informasi ini mempermudah proses penyeleksian data calon pegawai dan pembuatan laporan. Laporan sesuai dengan periode waktu yang diinginkan oleh perusahaan tanpa perlu melakukan pengurutan data secara manual.

Beberapa yang dapat diberikan oleh penulis dari sistem informasi ini adalah:

1. Perlu adanya pelatihan penggunaan sistem informasi ini kepada bagian HRD.

2. Aplikasi ini masih dapat dikembangkan sesuai dengan perubahan kebutuhan perusahaan nantinya.

\section{UCAPAN TERIMAKASIH}

Pada kesempatan yang baik ini, izinkanlah penulis menyampaikan rasa hormat dan ucapan terima kasih kepada seluruh pihak yang senantiasa ikhlas telah memberikan bantuan dan dukungan kepada penulis dalam menyelesaikan tugas akhir ini, terutama kepada:

1. Ibu Tuti Handayani, M.Kom., Selaku Dosen Pembimbing Materi Tugas Akhir yang telah begitu banyak membantu dalam memberikan bimbingan dan masukan-masukan selama penyelesaian laporan tugas akhir.

2. Ibu Rosdiana, M.Pd., Selaku Dosen Pembimbing Teknik dan Tugas Akhir yang telah begitu banyak membantu dalam memberikan bimbingan dan masukan-masukan selama penyelesaian laporan tugas akhir.

\section{DAFTAR PUSTAKA}

[1] Arief, Herdiansah. 2020. "Sistem Pendukung Keputusan Referensi Pemilihan Tujuan Jurusan Teknik Di Perguruan Tinggi Bagi Siswa Kelas XII IPA Menggunakan Metode AHP”. Jurnal Matrik, vol. 19 no. 2 Mei 2020. Universitas Bumigora. pp 223-224.
[2] H. Hariwijaya, Sukses Rekrutmen \& Seleksi Karyawan. Yogyakarta: Diandra Kreatif, 2017.

[3] Pertiwi, D.,D and Taufiq, R. 2020. "Analisis dan Desain Sistem Informasi Pengolahan Nilai Siswa di SMK Avicena Rajeg", J. Tek. Inform. Univ. Muhammadiyah Tangerang. ISSN: 25490710

[4] E. Saputra dan R. Wulan, "Analisis dan Perancangan Sistem Informasi UndangUndang Wakaf dalam Tata Kelola Lembaga Pendidikan Islam dan Hasil Belajar," Jurnal String, vol. 1, no. 2, pp. 214-222, 2016.

[5] E. Sugiarto, Menyusun Proposal Penelitian Kualitatif: Skripsi dan Tesis: Suaka Media. Yogyakarta: Diandra Kreatif, 2017.

[6] Sugiyono. Metode Penelitian Kuantitatif Kualitatif dan $R \& D$. Bandung: Alfabeta, 2012.

[7] Yurindra. Software Engineering. Yogyakarta: Deepublish, 2017. 